\title{
SISTEM PAKAR NARCOLEPSY DENGAN METODE FORWARD CHAINING
}

\author{
Suci Wahyuni \\ Universitas Putra Indonesia YPTK Padang \\ suci_wahyuni@upiyptk.ac.id
}

\begin{abstract}
Abstrak
Narkolepsi adalah suatu penyakit yang menyebabkan korbannya sering mendapat serangan kantuk, seperti gangguan tidur lainnya ia amat jarang dikenali oleh masyarakat. Narkolepsi juga merupakan serangan tidur dimana penderita sangat sulit mempertahankan keadaan sadar. Rasa kantuk bisa hilang apabila sudah tidur dalam waktu 15 menit namun kantuk akan datang kembali berikutnya, dan dimalam hari penderita narkolepsi tidak bisa tidur. Kebiasaan tersebut juga merupakan kendala yang sering dijumpai remaja atau pun para dewasa akhir-akhir ini, salah satu dampak negatif dari rasa kantuk tersebut adalah terkendalanya pekerjaan kita. Banyak diantara kita yang tidak menyadari penyakit yang ditimbulkan oleh narkolepsis, sehingga keterbiasaan itu memicu dampak buruk bagi tubuh. Menindaklanjuti hal demikian maka diciptakan sebuah sistem yang mampu memberikan informasi layaknya dokter kepada pasien terhadap narkolepsis dnegan menggunakan metode forward chaining. Dengan tujuan sistem dapat memberikan informasi terhadap dampat yang dihadapkan oleh narkolepsis. Sistem ini dibangun dengan menggunakan metode research dan development yang menunjuk pada output berupa aplikasi sistem pakar dengan pembacaan datanya dilakukan secara forward chaining.
\end{abstract}

\begin{abstract}
Narcolepsy is a disease that causes victims to often get drowsy attacks, like other sleep disorders he is rarely recognized by the public. Narcolepsy is also a sleep attack where the sufferer is very difficult to maintain a conscious state. Drowsiness can disappear if you have slept within 15 minutes, but drowsiness will come back next, and at night narcolepsy can not sleep. The habit is also an obstacle that is often found in adolescents or even adults lately, one of the negative effects of sleepiness is the constraint of our work. Many of us are not aware of the disease caused by narcolepsis, so that habit triggers a bad impact on the body. Following this up, a system was created that was able to provide information like a doctor to patients against narcolepsis using the forward chaining method. With the aim of the system can provide information on the impact faced by narcolepsis. This system was built using research and development methods which point to the output in the form of expert system applications with the reading of the data carried out by forward chaining
\end{abstract}

Kata kunci: Expert System, Forward Chaining, Narkolepcy

\section{Pendahuluan}

Narkolepsi adalah gangguan neurologis yang mempengaruhi kontrol tidur dan terjaga, dalam bahasa awam disebut sebagai "serangan tidur". Orang dengan pengalaman narkolepsi berlebihan kantuk di siang hari, episode tak terkendali jatuh tertidur pada siang hari. Seranga tidur tiba-tiba dapat terjadi dalam setiap jenis kegiatan pada setiap saat sepanjang hari. Perkiraan prevalensi angka kejadian berkisar antara 2-10 orang per 10.000 orang di Amerika Utara dan Eropa. Sedangkan di Jepang angka kejadian sekitar lima kali 
lebih tinggi. Gejala-gejala dari narkolepsi biasanya timbul antara usia 12 dan 30 tahun, meskipun ada pula kasus yang dilaporkan dengan penderita sejak usia 2 tahun dan hingga akhir 76 tahun. Perbedaan gender tidak terlalu berpengaruh terhadap prevalensi kejadian.

Dalam siklus tidur yang khas, orang akan memasuki tahap awal tidur diikuti dengan tahap tidur yang lebih dalam dan akhirnya (setelah sekitar 90 menit) terjadi gerakan mata cepat (REM/ rapid eye movement) tidur. Untuk orang yang menderita narkolepsi, tidur REM terjadi segera dalam siklus tidur, serta secara berkala selama jam bangun. Ketika tidur REM, kita dapat mengalami mimpi dan paralisis otot (kelumpuhan otot) - yang menjelaskan beberapa gejala narkolepsi.

Narkolepsi memiliki gejala awal yang ditandai dengan rasa kantuk yang tidak tertahankan di siang hari, lalu pada umumnya berlanjut dengan serangan tidur atau tidur secara tibatiba tanpa mengenal waktu dan tempat. Narkolepsi sebenarnya termasuk kelompok gangguan otak jangka panjang. Narkolepsi biasanya dimulai pada usia remaja dan awal usia dua puluhan. Banyak diantara kita yang tidak memahami dampak dari narkolepsi itu sendiri dan tak jarang diantara kita membiarkan kondisi tersebut tanpa mengevaluasi kejadian yang akan timbul dari keterbiasaan tersebut, hal terbebut terjadi karena minimnya informasi mengenai narkolepsi dan kurangnya kesempatan untuk berdiskusi dengan dokter perihal gangguan tidur.

Meminimalisir hal demikian maka perlu kiranya sebuah sistem yang membantu dalam memberikan informasi dampak dan bagaimana pencegahan dari narkolepsi terhadap tubuh. Sistem yang dibangun merupakan sistem pakar yang memindahkan kepakaran seseorang kedalam sebuah sistem, memunculkan informasi yang disampaikan oleh dokter kedalam sebuah sistem dengan cara pembacaannya dimulai dari penentuan gejala awal dari narkolepsi itu sendiri atau disebut dengan forward chaining.

Sistem pakar ini membantu pasien atau penderita narkolepsi untuk memahami kondisi awal dan dampak yang diberikan bagi penderita pada saat berkonsultasi dengan penyajian informasi yang jelas.

\section{Tinjauan Literatur}

Sistem Pakar (expert system) adalah sistem/program yang bertingkah laku seperti ahlinya atau pakarnya. Sistem pakar merupakan sistem yang berbasis pengetahuan digunakan untuk membantu menyelesaikan masalah-masalah yang ada dalam dunia nyata (Sutodjo, 2012).

\subsection{Sistem Pakar}

Sistem pakar terdiri dari dua bagian pokok, yaitu: lingkungan pengembangan (development environment) dan lingkungan konsultasi (consultation environment). Lingkungan pengembangan digunakan sebagai pembangun sistem pakar baik dari segi pembangunan komponen maupun basis pengetahuan. Lingkungan konsultasi digunakan oleh seseorang yang bukan ahli untuk berkonsultasi (Kusumadewi, 2013). 


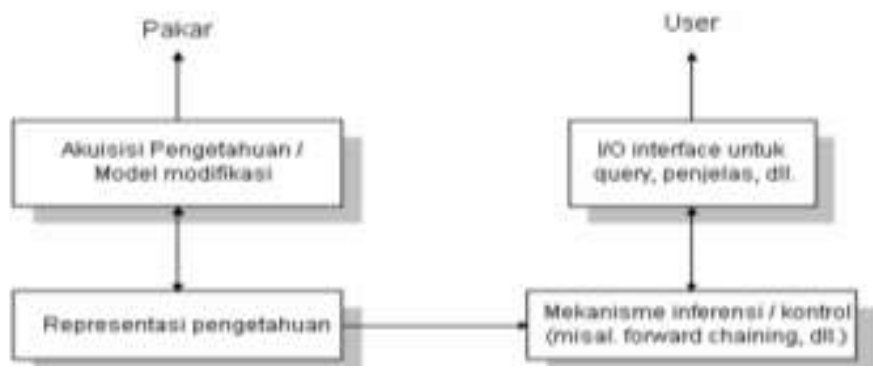

Gambar 2.1 Struktur Sistem Pakar

Komputer berbasis pengetahuan sistem pakar merupakan program komputer yang mempunyai pengetahuan berasal dari manusia yang berpengetahuan luas(pakar) dalam domain tertentu, di mana pengetahuan di sini adalah pengetahuan manusia yang sangat minim penyebarannya, mahal serta susah didapat.

Walaupun sistem pakar dapat menyelesaikan masalah dalam domain yang terbatas berdasarkan pengetahuan yang dimasukkan ke dalamnya, tetapi sistem pakar tidak dapat menyelesaikan yang tidak dapat diselesaikan manusia. Oleh sebab itu keandalan dari sistem pakar terletak pada pengetahuan yang dimasukkan ke dalamnya.

Kondisi-kondisi di mana sistem pakar dapat membantu manusia dalam menyelesaikan masalahnya, antara lain:

1. Kebutuhan akan tenaga ahli (pakar) yang banyak, tetapi pakar yang tersedia jumlahnya sangat terbatas.

2. Pemakaian pakar yang berlebihan dalam membuat keputusan, walaupun dalam suatu tugas yang rutin.

3. Pertimbangan kritis harus dilakukan dalam waktu yang singkat untuk menghindari halhal yang tidak diinginkan.

4. Hasil yang optimal, seperti dalam pencernaan atau konfigurasi.

5. Sejumlah besar data yang harus diteliti oleh pakar secara kontinu.

\subsection{Mesin Inferensi}

Inference engine merupakan otak dari sistem pakar, bagian ini mengandung mekanisme fungsi berpikir dan pola-pola penalaran sistem yang digunakan oleh seorang pakar. Mekanisme ini akan menganalisa suatu masalah tertentu dan kemudian mencari jawaban atau kesimpulan yang terbaik. Dari fakta-fakta yang diperoleh selama proses tanya-jawab dengan user, serta aturan-aturan yang tersimpan di knowledge base, inference engine dapat menarik suatu kesimpulan dan memberikan rekomendasi atau saran yang diharapkan oleh user. Beberapa pendekatan dalam penyusunan inference engine adalah seperti gambar berikut: 


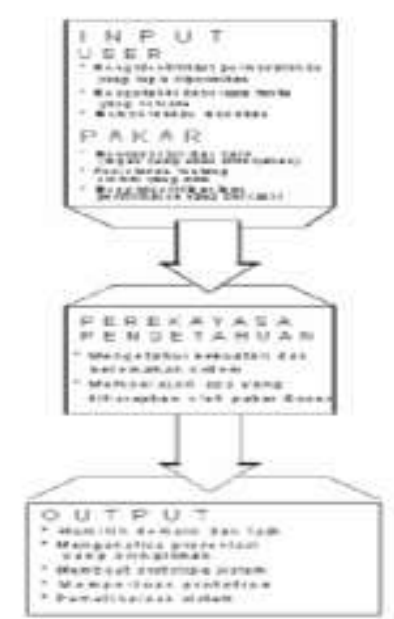

Gambar 2.2 Perekayasa Pengetahuan dengan IO Sistem Pakar

\subsection{Forward Chaining}

Kadang disebut:data-driven karena inference engine menggunakan informasi yang ditentukan oleh user untuk memindahkan ke seluruh jaringan dari logika 'AND' dan 'OR' sampai sebuah terminal ditentukan sebagai objek. Bila inference engine tidak dapat menentukan objek maka akan meminta informasi lain. Aturan (Rule) di mana menentukan objek, membentuk path (lintasan) yang mengarah ke objek. Oleh karena itu, hanya satu cara untuk mencapai satu objek adalah memenuhi semua aturan.

Jika dikondisikan terhadap 10 aktifitas dari sistem pakar yang menggunakan metoda forward chaining adalah sebagai berikut:

$$
\begin{aligned}
& R 1 \text { : if } A \text { and } B \text { then } C \\
& R 2: \text { if } C \text { then } D \\
& R 3: \text { if } A \text { and } E \text { then } F \\
& R 4: \text { if } A \text { then } G \\
& R 5: \text { if } F \text { and } G \text { then } D \\
& R 6: \text { if } G \text { and } E \text { then } H \\
& R 7: \text { if } C \text { and } H \text { then I } \\
& R 8: \text { if I and } A \text { then J } \\
& R 9: \text { if } G \text { then J } \\
& R 10: \text { if J then } K
\end{aligned}
$$

Fakta awal yang diberikan hanya $\mathrm{A}$ dan $\mathrm{E}$, ingin membuktikan apakah $\mathrm{K}$ bernilai benar. Proses penalaran forward chaining terlihat pada gambar dibawah : 


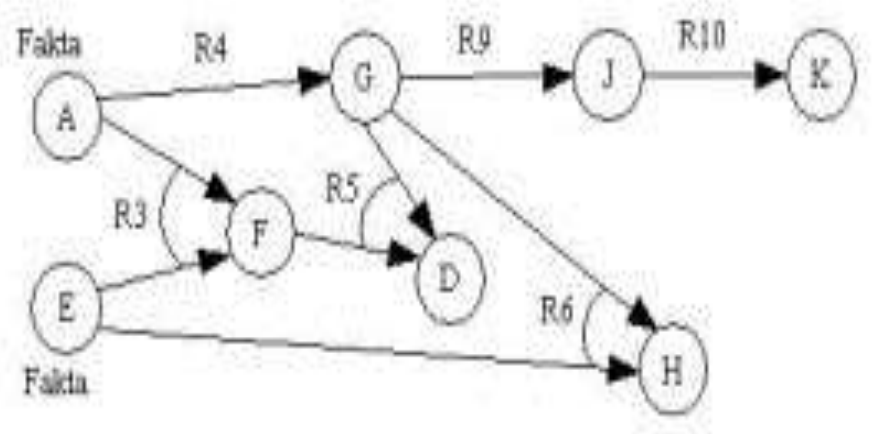

Gambar 2.3 Forward Chaining

\section{METODE PENELITIAN}

Kerangka kerja ini merupakan langkah-langkah yang akan dilakukan dalam penyelesaian masalah yang akan dibahas. Adapun kerangka kerja penetian dapat digambarkan pada gambar 3.1 berikut:

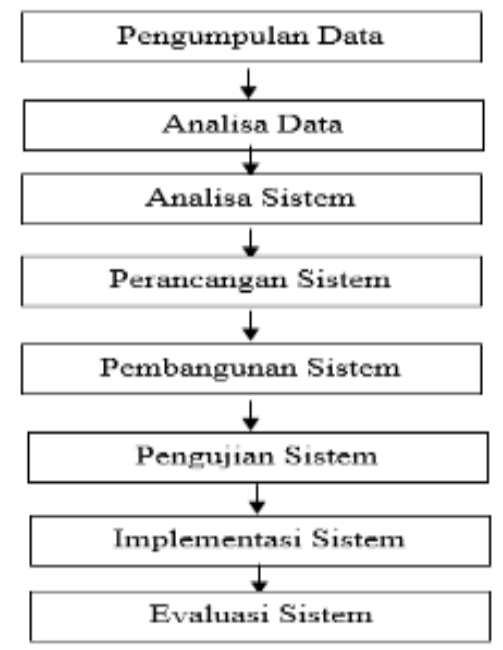

\section{Gambar 3.1 Kerangka Kerja Penelitian}

Dalam metodologi penelitian menggunakan model waterfall yang terdiri dari beberapa fase dalam pengembangan sistem yaitu perencanaan, analisis, desain sistem, pengujian dan implementasi, serta pemeliharaan. Pada fase desain sistem pakar ada beberapa tools yang digunakan untuk membangun sistem ini, alat yang digunakan dengan menggunakan model pendekatan terstruktur.

\section{Hasil dan Diskusi}

\subsection{Konteks Diagram}

Kontek diagram menggambarkan desain sistem secara keseluruhan atau secara umum dimana sistem ini terdiri dari entitas pakar dan admin, masukan kemudian diproses oleh sistem dan menghasilkan keluaran seperti terlihat pada Gambar 4.1. 


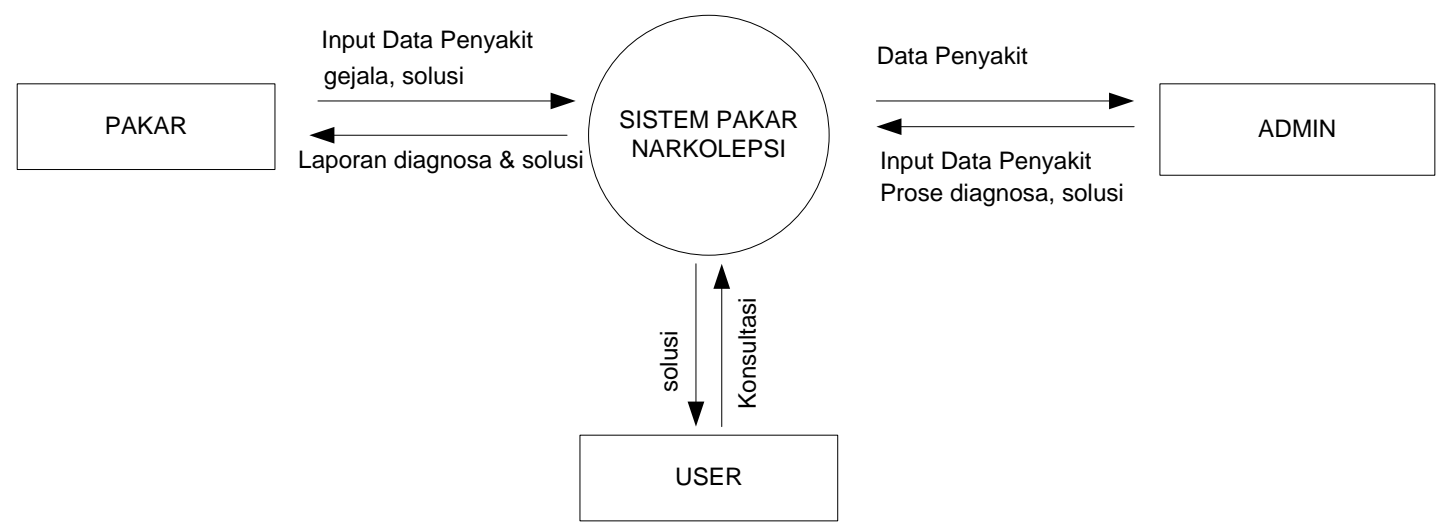

\section{Gambar 4.1 Konteks Diagram}

\subsection{Data Flow Diagram}

Data flow diagram level 0 menggambarkan orang yang menggunakan sistem selanjutnya diproses oleh sistem kemudian data disimpan pada data store, dari data yang telah disimpan tersebut dapat dipanggil kembali sesuai dengan keperluan pengguna sistem, seperti yang terlihat pada Gambar 4.2

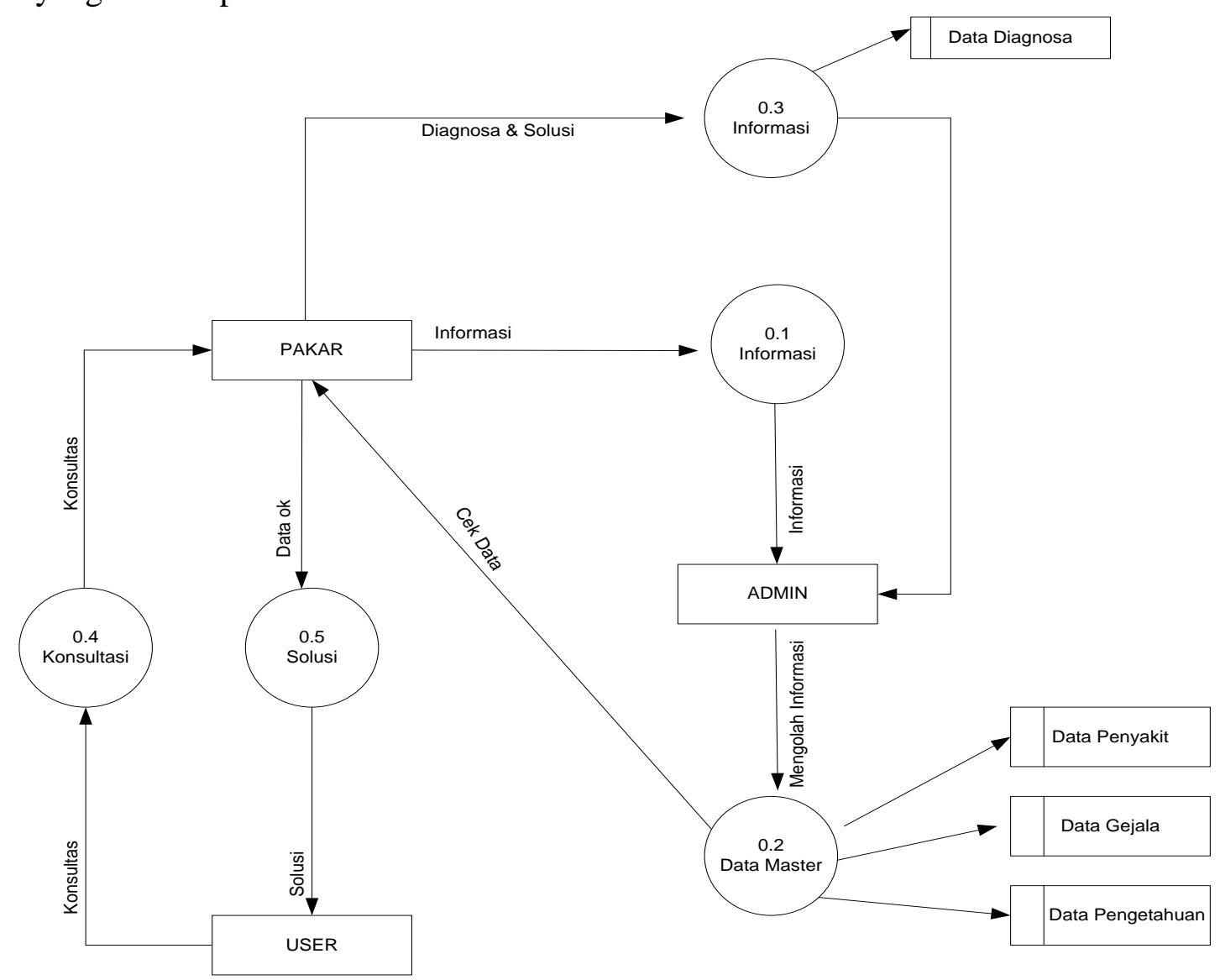

Gambar 4.2 Data Flow Diagram

\subsection{Entity Relationship Diagram}

Entity Relationship Diagram menggambarkan ketergantungan antara entitas-entitas yang ada sehingga dilakukan keterhubungan, ERD ini jika diimplementasikan pada program 
akan menjadi tabel-tabel yang saling berhubungan pada SQL (Structure Query Language), seperti terlihat pada Gambar 6.

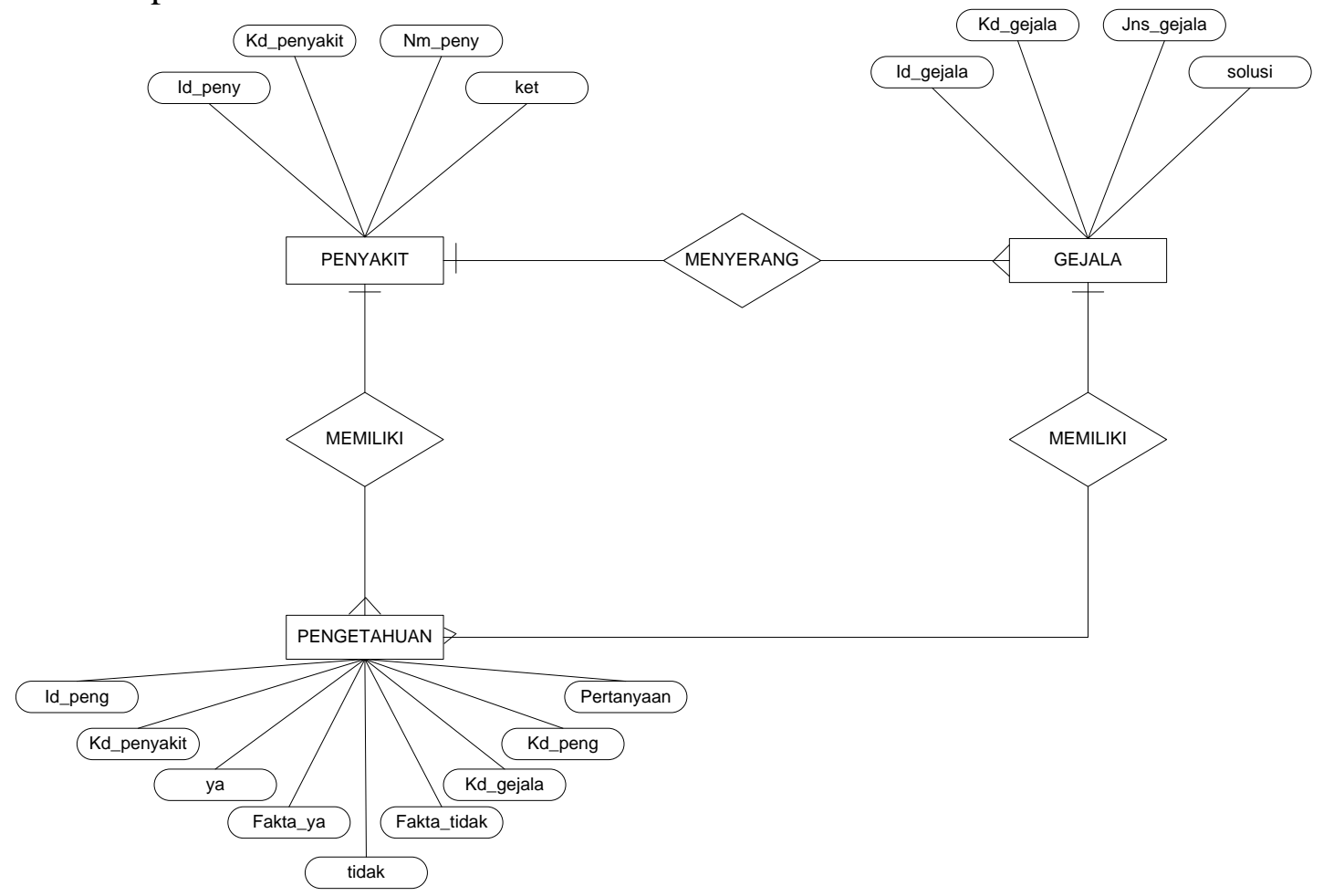

Gambar 4.3 ERD Basis Pengetahuan

Proses yang dilakukan pada fase basis pengetahuan dipresentasikan dengan langkahlangkah berikut yaitu: (1) Menentukan tabel basis pengetahuan, (2) Menyusun rules (aturan gejala), (3) Menentukan tabel keputusan dan (4) Membuat pohon keputusan. Proses ini terlihat pada Tabel 1, 2 dan 3.

Tabel 1.1 Basis Pengetahuan Data Penyakit

\begin{tabular}{|l|l|}
\hline Kode Penyakit & Dampak \\
\hline P001 & Cedera Pada Otak \\
\hline P002 & Penyakit Pada Syaraf \\
\hline P003 & Genetik \\
\hline
\end{tabular}

Tabel 1.2 Tabel Gejala

\begin{tabular}{|l|l|}
\hline Kode Gejala & Keterangan \\
\hline G001 & Rasa Kantuk Berlebihan Di siang Hari \\
\hline G002 & $\begin{array}{l}\text { Kehilangan ketebalan otot secara tiba- } \\
\text { tiba }\end{array}$ \\
\hline G003 & Lumpuh tidur/sleep paralysis \\
\hline G004 & Halusinasi \\
\hline G005 & Infeksi \\
\hline G006 & Stress \\
\hline G007 & Terkena Racun \\
\hline
\end{tabular}




\section{PENGUJIAN SISTEM}

Pengguna program ini dapat mengidentifikasi informasi yang terkait dengan sistem pakar mendiagnosa dampak penggunaan softlens, untuk lebih jelas dapat dilihat pada proses berikut.

\subsection{Diagnosa narkolepsi}

Jika melakukan diagnosa maka pengguna masuk ke form diagnosa mengisi data pasien jika sudah selesai maka lanjut menekan tombol diagnosa lalu pilih jenis penyakit dan selanjutnya akan masuk ke form pertanyaan. Terlihat pada Gambar 8.

\subsection{Form Konsultasi}

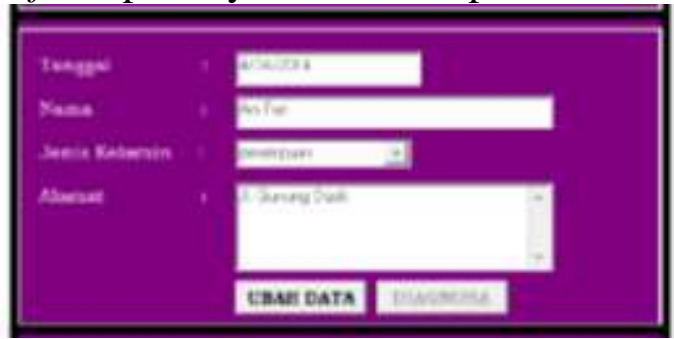

Gambar 5.1 Input data Pengguna

Form pertanyaan ini akan menentukan gejala apa saja yang terdapat dari penyakit pada penderita pengguna narkolepsi. Terlihat pada Gambar 6.2.

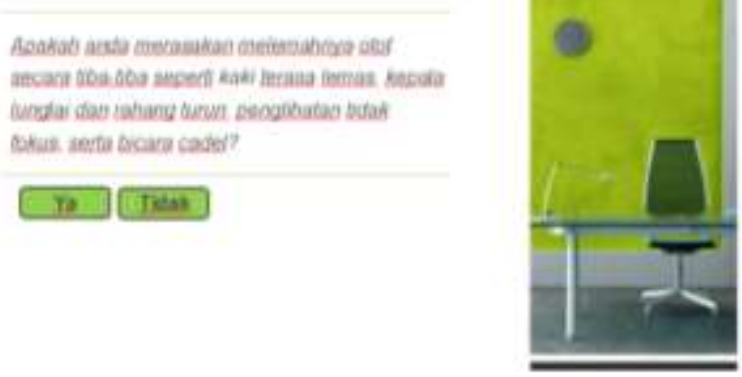

\subsection{Form Solusi}

\section{Gambar 5.2 Form Konsultasi}

Form ini merupakan tahap akhir dari proses pertanyaan yang berisikan solusi dan keterangan mengapa terkena penyakit tersebut. Terlihat pada Gambar 10.

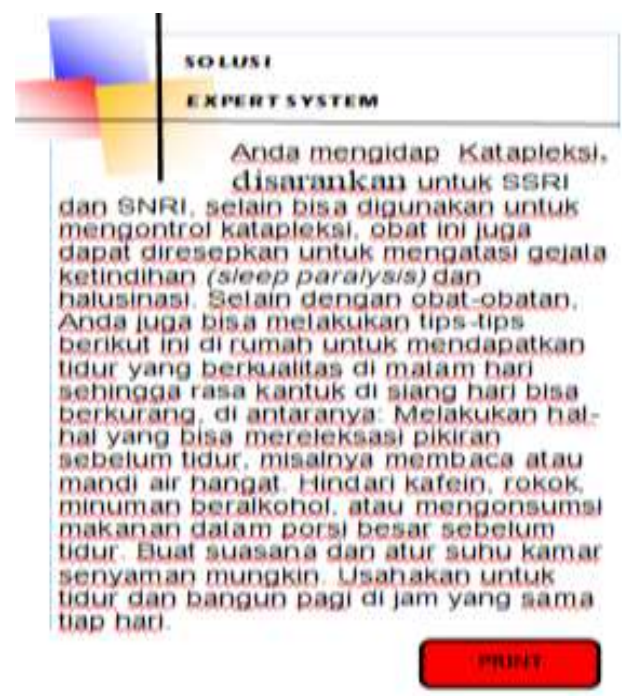

\section{Gambar 5.3 Solusi}




\section{KESIMPULAN}

Adapun kesimpulan yang dapat diambil dari pembahasan skripsi ini adalah:

1. Memahami dampak dari kebiasaan mengantuk yang setiap saat terkadang mengganggu aktifitas

2. Pasien atau masyarakat lebih leluasa berkonsultasi dengan sistem tanpa mengenal waktu

3. Sistem Pakar Narkolepsi dapat membantu dalam berbagai kegiatan pemberian informasi atau pengetahuan kepada pasien (masyarakat).

4. Penerapan metode Forward Chaining merupakan alternatif dalam pembacaan data yang bertujuan untuk memudahkan user atau pasien dalam mengetahui gejala yang ditimbulkan dari narkolepsi itu sendiri.

\section{DAFTAR PUSTAKA}

Asrianda dan Fadlisyah.2008."Pemrograman Database (Konsep dan Implementasi)". Yogyakarta:Graha Ilmu.

Darmayuda, Ketut . 2014. Aplikasi Basis Data dengan Visual Basic. NET. Bandung: Informatika Bandung.

Enterprise, Jubilee. 2014. MySQL Untuk Pemula. Jakarta: PT Elex Media Komputindo.

Gunawan, Kesuma Prananingrum dan Ririn dan Wigati Restu Ruwilin. 2013.

"Pengembangan Sistem Penunjang Keputusan Penentuan Pemberian Beasiswa Tingkat Sekolah". ISSN Vol 14, No 2, Oktober 2013.

Heryanto, Imam. 2012. "Membuat Database Dengan Microsoft Access". Bandung: Informatika Bandung.

Hirin. 2011. "Belajar Tuntas VB. NET 2010. Jakarta: PT. Prestasi Pustakaraya

Jaya,putra. 2013. "Sistem Pendukung Keputusan Penentuan Bonus Karyawan Menggunakan Metode Weighted Product (WP)". ISSN Vo V, No 2, Desember 2013.

Jogianto,H.M.2000." Analisis \& Desain Sistem Informasi: Pendekatan Terstruktur, Teori dan Praktik Aplikasi Bisnis".'Yogyakarta:Andi Offset.

Jogianto,HM.2008."Pengantar Teknologi Informasi".'Yogyakarta:Andi.

Kadir, Abdul.2003.'Dasar Pemrograman Java2"'.Yogyakarta:Andi Offset

Madcoms, Andi.2003."Aplikasi Database Visual Basic dengan Cristal Report". Yogyakarta:Andi Offset.

Nugroho, Bunafit.2008. 'Database Relasional dengan MySQL”.Yogyakarta:Andi Offset.

Nugroho,Andi.2004."Analisis dan Perancanagan Sistem Informasi dengan Metodelogi Berorientasi Objek Edisi Revisi"..Bandung:Informatika.

Oetomo, Budi Sutedjo Dharma.2006."Perencanaan \& Pembangunan Sistem Informasi"'.Yogyakarta:Andi Offset.

Pratama, I Putu Agus Eka. 2014. Sistem Informasi dan Implementasinya. Bandung: Informatika Bandung.

Pratama, Ramadhani Noor dan Faslah Ronny. 2014. "Implementasi Metode Weighted Product Terhadap Sistem Pendukung Keputusan Seleksi Usulan Pengadaan Dari Puskesmas Di Dinas Kesehatan Kota BanjarBaru". ISSN Vol 2, No 2, Oktober 2014 
Putra Apriansyah dan Hardiyanti Yunika Dinna. 2011. "Penentuan Penerimaaan Beasiswa Dengan Menggunakan Fuzzy Multiple Atribute Decission Makin". ISSN Vo.3, No.1 April 2011.

Rani, Sasika. 2014. "Sistem Pendukung Keputusan Pemilihan Sepeda Motor Berbasis Web Dengan Metode Weighthed Product". ISSN Vol Vil, No 3, Agustus 2014.

Sanjaya, Ridwan.2005. "Pengolahan Database MySQL 5 dengan JAVA 2 disertai Teknik Pencetakan Laporan".'Yogyakarta:Andi Offset.

Sutabri, Tata. 2012. Analisis Sistem Informasi. Jakarta: CV ANDI OFFSET

Togatorop, Fernandex dan Arnando. 2015. "Penerapan Metode Weighted Product (WP) Dalam Sistem Pendukung Keputusan Penilaian Kinerja Karyawan Pada PT. Johan Sentosa Kab.Kampar". ISSN Vol V, No 2, Januari 2015.

Wahana Komputer.2012."Panduan Aplikatif \& Solusi(PAS) Membangun Aplikasi Bisnis Dengan Netbeans 7’.Yogyakarta:Andi Offset

8. 